\title{
Administrative Federalism
}

\author{
Nathalie Bebnke and Sabine Kropp
}

\section{INTRODUCTION}

The German federal state has frequently been analysed through the lens of 'administrative federalism' (see, e.g., Hueglin and Fenna 2015: 54). This denotation builds on two basic dimensions. On the one hand, it emphasises that governments and administrations at all territorial levels are powerful actors in policymaking and implementation processes. On the other hand, compared to other federations, the German model implies that legislation predominantly takes place at the federal level, while the Länder (the relevant political sub-federal units) implement federal laws in their own right, through their own administration and at their own cost (Kuhlmann and Wollmann 2019: 93). This specific federal architecture is inherited (as elaborated in Sect. 2) and entails a specific distribution of responsibilities and functions (as elaborated in Sect. 3; see also the chapter

N. Behnke $(\bowtie)$

Technical University of Darmstadt, Darmstadt, Germany

e-mail: nathalie.behnke@tu-darmstadt.de

S. Kropp

Free University Berlin, Berlin, Germany

e-mail: sabine.kropp@fu-berlin.de

(C) The Author(s) 2021

S. Kuhlmann et al. (eds.), Public Administration in Germany, Governance and Public Management, https://doi.org/10.1007/978-3-030-53697-8_3 
by Schrapper). Accordingly, the strength of the Länder is not rooted in exclusive jurisdictions and self-rule, but based on their extensive rights to co-decide on federal bills and their prerogative to implement federal laws.

Consequentially, Länder administrations are embedded in a dense network of vertical and horizontal relations. Two (types of) organisational bodies are particularly relevant for securing coordination both horizontally among the Länder and vertically between the entire Länder and the federal level: the Bundesrat and the various ministerial councils, among which the prime ministerial council (Ministerprösidentenkonferenz) is the most prominent, as will be elaborated in Sect. 4 .

In other federal states providing a more dual federal architecture, such as the United States or Switzerland, horizontal intergovernmental councils primarily fulfil the function of protecting sub-federal policymaking or policy implementation from federal encroachment. Second chambers, where they exist and have some meaningful role in legislation, rarely represent sub-federal interests. By contrast, in Germany, both (types of) bodies represent effective arenas for multilateral coordination, thereby providing various venues for debating and deciding potentially contentious issues. They also serve as arenas where conflicts can be averted at an early stage of the political process. This consensual culture of decisionmaking in multilevel structures was illustratively described as entangled or interlocking politics (a more or less clumsy translation of Politikverflechtung as coined by Fritz W. Scharpf). While critics claim that this cooperative, multilateral decision-making style might lead at best to incremental change, or even to outright decision deadlock, it turned out that these bodies have contributed to a surprisingly high effectiveness of German federalism and a concomitantly low level of litigation between the units of government.

\section{Historical RoOts of German Administrative Federalism}

The peculiar German model of administrative federalism is deeply rooted in German history. Although the German Basic Law was drafted from scratch after the breakdown of the totalitarian regime and the end of the Second World War in 1945, constitutional key institutions were conspicuously taken from federal experiences in the German past and adapted to the requirements of the newly established federal democratic institutional 
setting. Especially the period from 1867 to 1871 is perceived as a 'critical juncture' in German administrative federalism (Weichlein 2012: 112).

Three basic features have decisively shaped administrative federalism: first, most notably, the executive character of the Bundesrat; second, the principle of administrative connectivity (Verwaltungskonnexität); and third, the vertical division of powers that runs along functions but not along policies, a principle which entails coordination and cooperation between various governments and bureaucracies across all policy fields. Consequently, bureaucrats are strong players in these intergovernmental settings, because they make coordinative and cooperative activities work (Behnke 2019).

The German empire's constitution adopted in 1871 (Reichsverfassung) fostered the administrative character of German federalism. In the nineteenth century, former independent territorial units pooled their sovereignty in order to unite and establish the German nation-state. Most importantly, the Bundesrat was designed as an assembly of Länder representatives, holding legislative as well as executive powers (Frotscher and Pieroth 2018: 209-212). And the Bundesrat, representing Länder governments, partially assumed functions of the federal government, which was still weak at that time and had to resort to Länder contributions and their administrative resources. Furthermore, as an embodiment of the authoritarian state, the Bundesrat enabled the former federal chancellor, Otto von Bismarck, to circumvent parliamentary accountability (Weichlein 2012: 113). Hence, federalism served as a 'fence', protecting the governments and their bureaucracies against parliamentarisation and the upcoming emancipation of the working class. The Bundesrat was designed to secure the prerogative of the emperor over the Reichstag; for the time being, it also helped regional sovereigns to contain the state parliaments' growing demands for participation.

Since the nineteenth century, the federal government has not been responsible for implementing its own laws, even though residual federal administrative responsibilities do meanwhile exist (Mußgnug 1984: 189). As a rule, the Länder executives implemented (and still implement) federal laws and bear the cost involved (Verwaltungskonnexität). On the other hand, since the Länder take over administrative responsibility for federal matters, they must also be involved in federal legislation, which was (and still is) executed with the requirement that all federal bills pass the Bundesrat. The concomitant functional division of labour necessitated intergovernmental coordination and fostered entanglement among the 
federal units. The developing welfare state and expanding infrastructure (railway construction, trade etc.) pressured governments to find unitary solutions, thereby strengthening cooperation between executive actors across territorial levels. Finally, a legalistic administrative culture developed during the nineteenth century, underpinning since then the German federal culture.

The constitution of the Weimar Republic (1918-1933) did not substantially alter this basic architecture. After the breakdown of the Nazi regime, which had abrogated federalism in 1934, the allies advocated federalisation and decentralisation as a means of containing any potential misuse of governmental power. During the early post-war period (1945-1949), the heads of Länder governments (the minister presidents) were leading figures in framing the constitutional debate. Concomitantly, before the Federal Republic was founded in 1949, the ministerial bureaucracies of the Länder had already begun to apply horizontal cooperation in various policy fields. After controversial debates in the parliamentary council (Parlamentarischer Rat) on drafting the Basic Law in 1948-1949, its representatives ultimately rejected the US-style senate model, which would have stipulated the popular election of senators. Preferring the involvement of Länder governments in federal legislation to the principles of immediate legitimation and self-rule, the fathers and mothers of the Basic Law returned to the Bundesrat model. In contrast to the 1871 constitution, parliamentary majorities now hold the post-war Länder governments accountable; administrations are agents of fully democratised governments. Nevertheless, the administrative character of German federalism is still anchored in the Bundesrat and its committee structure, composed of Länder bureaucrats rather than elected politicians, and is reflected in a dense web of inter-administrative bodies.

\section{Distribution of Responsibilities}

In West Germany after the end of the Second World War (1949) and East Germany after reunification (1990) (see the chapter by Wollmann), power was organised in a highly decentralised fashion, granting the Länder and their municipalities with a large number of jurisdictions. Power is divided in the 'vertical' dimension between two levels of government- the federal level and the sixteen Länder. The local authorities are formally lower administrative units of the Länder, but Article 28 of the Basic Law accords them extended rights of autonomy, in particular a functional omnipotence 
within the territorial boundaries of their jurisdiction (see the chapter by Bogumil/Kuhlmann). Intermediate layers exist 'in between' the local and the Länder level. Higher communal associations (böhere Kommunalverbände) bundle local authorities' administrative capacities for a larger territory. District organisations (Regierungspräsidien) are allpurpose sub-units of the Land ministry of the interior exercising direction, control and oversight over the execution of Länder tasks in the respective territory. In addition, there are functionally specialised Länder offices, for example, environmental offices, health offices and statistical offices, to name but a few.

Division of labour between the federal level and the Länder is organised mainly along a functional logic, yet overlapping with a policy-specific logic. Functionally, the federal level holds the majority of legislative powers, while the Länder and local authorities fulfil the overwhelming part of executive functions. Policy-wise, a few exceptions exist. For example, the Länder have retained legislative competences for culture, education and police and some minor competences. They also have considerable organisational autonomy and decide how they implement policies. This even extends to the regulation of local charters, local fiscal equalisation systems and local responsibility for certain tasks. The division of legislative powers is elaborated mainly in Articles 72 and 74 of the Basic Law. The federal level, on the other hand, relies predominantly on Länder administrations to fulfil its tasks. In the case of a few tasks, which are deemed to be of exclusive federal nature, the federal government staffs its own offices at the local level across the territory. These include, for example, the military services, the customs and duty administration, and the intelligence services, as well as the Federal Unemployment Agency and the Federal Office of Migration and Refugees (see Article 87 of the Basic Law).

If the activities of the Länder administrations relate to federal laws, the administrations act on behalf of the federal government. If they execute their own laws, they act autonomously. This distinction is laid down in Articles $83-85$ of the Basic Law and has implications for the intensity with which the federal government may structure administrative processes and organisations in all Länder alike, thereby securing uniform standards of public service delivery. The Länder, for their part, can delegate their tasks to the local authorities, where basically the same principle applies: the local authorities, as administrative units that have direct contact with citizens as addressees of norms or as requesting services, act on their own behalf if they perform tasks that fall within the concept of local autonomy. If they 
take on tasks that have been transferred to them by the Länder, they must respect the regulations given by the Länder and are subject to legal and functional oversight (Fachaufsicht) (see Fig. 3.1).

As a rule, the formal power distribution assigns clearly delineated jurisdictions to each level of government or to single territorial units, thereby establishing political accountability and responsibility for the effective and efficient fulfilment of tasks. However, joint provision of tasks across levels of government severely hampers these principles. Nevertheless, with the constitutional reform of 1969 , administrative coordination has intensified. The reform defined a considerable number of policy issues such as regional and economic development and the construction of university buildings as joint tasks to be planned, implemented and financed jointly by the federal government and the Länder (Articles 9la and 9lb of the Basic Law). This instrument of joint tasks has been extended to other policy areas, such as labour administration, digitalisation (see the chapter by Mergel) and comparison of education levels (Articles 9lc-9le of the Basic Law). Beyond these constitutionally prescribed joint tasks, voluntary horizontal and vertical cooperation is a pervasive feature of administrative practice in Germany's federal system, as will be discussed further in the next section. The motives for cooperation include, for example, striving for best practices, economies of scale and uniform implementation. In instances of vertical or horizontal cooperation between the Länder and the federal level, self-regulatory bodies are often established and jointly staffed by all units

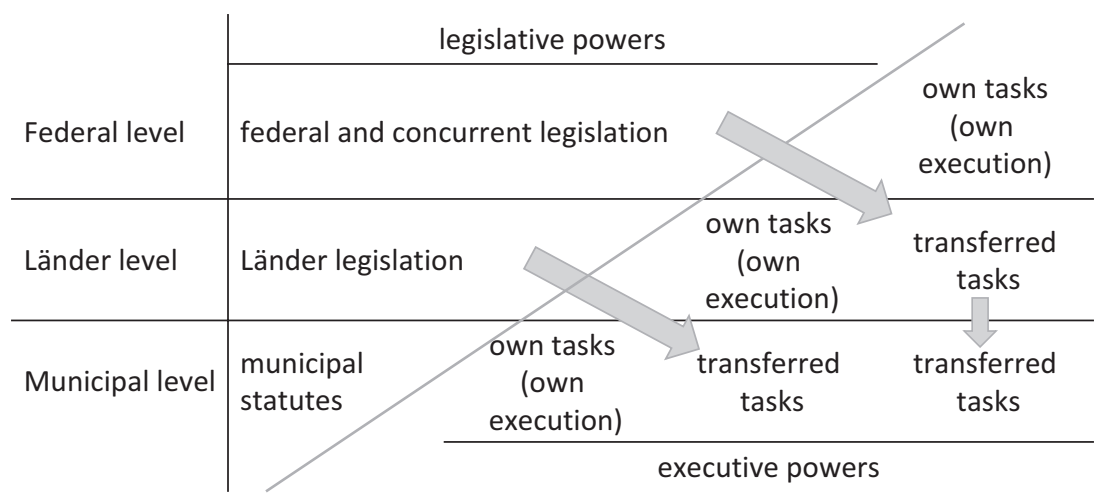

Fig. 3.1 Functional division of labour in the federal hierarchy 
involved in order to monitor the negotiation process and to govern implementation (e.g. the stability council or the IT planning council).

Financial management largely follows the principle of administrative connectivity, meaning that the unit responsible for executing a task or providing a service is obliged to finance it. The rationale behind this principle is to ensure a responsible spending behaviour. As is shown in Fig. 3.1, local authorities shoulder responsibility for the largest share of executive tasks. As they have the smallest allocation of financial resources, the higher levels of government transfer funds by means of tax sharing, fiscal equalisation payments or grant systems to the local level (see the chapter by Färber). Naturally, federal, Länder and local governments have diverging opinions about the amount of fiscal transfers necessary to fulfil tasks appropriately. Over the past decades, two trends have become apparent. First, taxes are increasingly being levied collectively. They are distributed in complex nested processes in order to empower each political and administrative unit to finance its own tasks. Second, with increasing amounts being spent by local authorities on welfare state payments, the federal government is willing to adopt larger shares of these payments by transferring money directly to the Lënder level (e.g. according to Article 104a of the Basic Law). Nonetheless, in spite of this fundamentally cooperative attitude, the level of payments to be made gives rise to much litigation, in particular between local authorities and the Länder.

To sum up, the vertical division of power is marked by a predominantly functional allocation of powers, whereas units with territorial jurisdictions and units with functional jurisdictions overlap across the German territory. Control and oversight are exercised mainly by the Länder over their local authorities, whereas the relationship between the Länder and the federal level is essentially non-hierarchical but marked by mutual rights of codecision-making, which are exercised in various negotiation arenas (such as joint task committees). This multi-layered and strongly decentralised administration is consistent with Germany's federal tradition and bolstered by a logic of subsidiarity and autonomy. It is balanced, however, by a deeply engrained administrative culture of cooperation and coordination. This specific manifestation of administrative federalism creates-in comparison to other federal architectures-a unique mix of decentralised decision-making, while securing policy homogeneity and a low level of litigation. 


\section{Coordination and CoOperation: Making Administrative Federalism Work}

The allocation of powers to territorial units provides the formal structure for policymaking. Yet, the everyday work of administrations requires constant processes of communication, information and coordination between governments and bureaucracies. These processes of intergovernmental relations are what makes federalism work in everyday politics. Intergovernmental communication and negotiations are institutionalised mainly in two arenas: in Bundesrat sessions and in regular meetings of ministerial conferences. Additionally, a multitude of informal meetings, working groups or task forces emerge and disappear on single issues. Undoubtedly, the most prominent institution providing an institutionalised framework for intergovernmental relations is the Bundesrat. According to Article 50 of the Basic Law, "(t)he Länder shall participate through the Bundesrat in the legislation and administration of the Federation and in matters concerning the European Union'. This prescription implies a dual function: while the Bundesrat is a second chamber and, as such, involved in federal legislation, due to its composition and working mode, it also serves as a crucial arena for intergovernmental activities (Hegele 2017). The Bundesrat co-decides on every federal bill. Around 38-60 percent of all bills in post-war history have been consent bills requiring an absolute majority of votes in the Länder assembly. Bills typically require consent if they affect finance and tax issues. Most importantly, however, bills stipulating that the Länder administrations execute federal laws in their own right trigger the consent rule. The federalism reform of 2006 relaxed some of these requirements and the percentage of consent bills has since decreased from an average of 55 percent per legislative period to an average of 39 percent (Stecker 2016: 614).

The Bundesrat meets roughly every four weeks and in each plenary session votes on about fifty federal bills. In order to shoulder this enormous workload, it is organised in working committees, which are at the top of the administrative coordination pyramid (Hoffmann and Wisser 2012: 601 ) and are bolstered by numerous more or less formalised administrative bodies and a dense network of informal administrative ties. Most committees are composed of higher-ranking civil servants (Ständige Sitzungsvertreter) from the respective Länder ministries, but in some committees (i.e. finance), the minister himself or herself takes part. In other 'political committees' (i.e. defence or foreign relations), the minister 
presidents themselves are involved, since these exclusive federal jurisdictions are naturally not mirrored in the Länder cabinets (Sturm and Müller 2013: $147 \mathrm{f}$.). The discourse in the committees is considerably shaped by the administrative and legal expertise of their members. As participants must often decide on dozens of issues during one meeting, generalists rather than policy specialists participate (Hoffmann and Wisser 2012: 607). Before the meetings, however, the highly specialised civil servants employed in the respective divisions of the Länder ministries are required to prepare the issues within a short time period (usually six weeks; see Article 76 (2) of the Basic Law).

In intergovernmental negotiations, territorial, party-based and issuespecific interests interact (Toubeau and Massetti 2013). For example, if distributive programmes, fiscal or tax issues are on the agenda, territorial interests usually prevail over party positions. Notwithstanding, decisionmaking in the Bundesrat plenary sessions depends on political constellations. As the coalition landscape at the Länder level—and thus the political composition of the Bundesrat - has become increasingly 'multi-coloured' since reunification, majorities nowadays are more often incongruent or even cross-cutting between the Bundestag and the Bundesrat. As part of the Länder governments, coalition parties need to agree on a common voting behaviour because each Land government must cast its votes en bloc (Article 51 (3) of the Basic Law). Accordingly, Länder coalitions stipulate in their coalition treaties that the government abstain from voting in the Bundesrat should the parties in government be unable to come to an agreement. This kind of two-level bargaining, which takes place simultaneously within the federal and Länder governments and across the federal units, is, in theory, prone to blockade. Under these conditions, one may find it surprising that the Bundesrat has so far voted against a remarkably small fraction of bills; the arbitration committee has only been invoked on rare occasions. From 1994 to 2017, the number of disapproved bills and arbitration committee meetings decreased significantly (from 2.5 percent and 14 percent to 0.1 percent and 0.5 percent, respectively, according to the official statistics on the Bundesrat website).

Certainly, party ideology is a relevant factor in shaping Bundesrat negotiations. Compromise and coalition building occur along party lines and across territorial interests, since Bundesrat members from the different Länder meet in political pre-negotiation circles-so-called A-rounds (Social Democrats), B-rounds (Christian Democrats) and G-rounds (the Greens). Yet, the final vote is shaped by various competing factors. First, 
even if majorities diverge between the Bundestag and the Bundesrat, a conflict of interest between the federal and Länder governments is managed by the practice that, already at the drafting stage of a bill, the federal legislator usually considers the preferences of Länder governments and adapts drafts according to the given majority situation (Burkhart and Manow 2006). Second, party organisations have been decentralised in recent years to a degree that has allowed Länder parties to place strong emphasis on territorial interests (Detterbeck 2012: 131ff.), which may cross-cut traditional party lines and open up new options for majority building. Third, civil servants who are involved in everyday legislative work share a similar professional understanding of their job and can moderate party ideological conflicts within bureaucratic networks. Recent research reveals a moderate party politicisation in the Bundesrat committees which prepare Bundesrat votes (Souris 2018). They share a strong identity as neutral experts in their respective policy fields. At the same time, expertise and party logics are not mutually exclusive; civil servants usually anticipate the will of their political leadership (Mayntz and Scharpf 1975). Depending on the political salience of the issue at stake, civil servants can 'domesticate' party politicisation, and often ministers and the cabinet follow their bureaucrats' expert advice (on civil servant politicisation; see also the chapter by Jann/Veit). Thus, depending on the polarisation of an issue, the administrative model of federalism can be quite effective in containing party conflict in federal coordination (Hoffmann and Wisser 2012).

The second set of relevant intergovernmental arenas besides the Bundesrat are so-called ministerial conferences, eighteen sectoral intergovernmental councils composed of ministerial bureaucrats from the Länder governments, who are sometimes joined by their counterparts from the federal level (Hegele and Behnke 2017). In addition to the sectoral conferences, the minister presidents' conference is the most prominent coordination arena of the Länder governments. Historically, the earliest ministerial conferences were founded in Germany after the Second World War, with the most recent (integration) being added in 2007. While administrative negotiations in the realm of Bundesrat sessions serve to provide input from administrative practice to legislative proposals, the meetings and autonomous working groups in and around ministerial conferences serve primarily to coordinate Länder interests during other stages of the policy cycle. They can be used to put issues on the political agenda, to influence pre-legislative negotiations or to coordinate policy 
implementation. Broadly, these meetings serve as a platform to exchange information, form coordinated positions, exert pressure and influence at the federal level, or to harmonise implementation practices. If issues on a ministerial conference's agenda are simultaneously being debated in a legislative bill in the Bundesrat, then typically the conference drops the issue to avoid a parallel discussion. Nevertheless, the decision as to which venue to choose if an issue is to be promoted politically-in a ministerial conference or in the Bundesrat-is also subject to strategic considerations. In that sense, the two arenas complement each other as fora of intergovernmental relations.

In the conferences, and even more so in the working groups, the logic of bureaucratic decision-making predominates over the logic of political decision-making. This is even more pronounced than in the Bundesrat and its committees, although it is in part the same persons who attend both fora. Indeed, the bureaucrats negotiating in ministerial conferences are well aware of the fact that they represent their home department presided by a minister who is, at the same time, member of a coalition party in government. They strive to act as 'honest brokers' for their ministers' political aims within the limits of factual expertise and consensus orientation. However, German civil servants essentially define their role as experts responsible for a policy field and, in accordance with the Weberian legalistic tradition, as advocates securing the rule-bound implementation of law (Hustedt and Salomonsen 2018). Surveys gathering data on the role definitions of political bureaucrats in the higher ministerial ranks suggest that the bureaucrats perceive themselves as representatives of the state but reject the role of party delegates (Mayntz and Derlien 1989; Schwanke and Ebinger 2006: 243). Due to continued coordination, vertical administrative 'brotherhoods' are sustained along policy areas, cutting across the levels of government and even stretching to the EU level.

While federal-Länder relations are well institutionalised and partly constitutionally guaranteed, the local authorities have a harder standing in the multilevel game. Without formal involvement in federal legislation and being dependent on the decisions of Länder governments, they must rely on lobbying, negotiation and informal representation in federal and Länder institutions. As a result, communities have formed associations of interest representation, some dating back more than a hundred years such as the Deutsche Städtetag (German Cities Association), the Städte- und Gemeindebund (Federation of Cities and Municipalities) and the Landkreistag (Counties' Association). Endowed by their members with 
financial resources and the power to speak in their name, these associations have intensely lobbied federal legislative processes. They have acquired an undisputed position as experts in hearings and an informal chair in federalLänder negotiations. To name just one example, it was due to the persistent intervention on the part of the Counties Association that new provisions were added to Articles 84 and 85 of the Basic Law in the 2006 constitutional reform protecting local authorities from an uncontrolled increase in tasks and concomitant financial burdens.

To sum up, multiple formal and informal, more or less institutionalised, and in part constitutionally guaranteed committees, councils and regular meetings are the backbone of intergovernmental relations. While federal and Länder levels are constitutionally on a fairly equal footing with the guaranteed participation of the Länder in federal legislation by means of the Bundesrat, the local authorities are in a more precarious situation and need to rely on lobbying to secure their influence on multilevel decisionmaking. In all these institutions and processes, bureaucrats from all levels of government play a crucial role in providing and exchanging information, defending positions, communicating and negotiating policies. Thereby, political ideology and conflict are mediated to a large extent. While they definitely shape position-taking by intergovernmental actors, they rarely develop disruptive power. As a rule, multilevel decision-making proceeds far more smoothly than the complicated formal network of entangled powers, institutions and processes would suggest.

\section{Trends and Challenges}

In recent decades, the steadily increasing Europeanisation of the German institutional setting has further bolstered administrative federalism, since bureaucratic networks, which are organised along policy fields, connect EU, federal and Länder (including local) actors and institutions. In fact, the German model of federalism has proved rather successful in coping with the challenge of creating institutional complementarity across the various territorial levels. It matches the European institutional setting, as it reflects its explicit executive character. In the intertwined European and German multilevel systems, executives of the lower territorial units participate in legislation at the respective higher level, thereby joining executive and legislative functions. This construction clearly empowers administrative actors. In Brussels, national (and sub-federal, if exclusive jurisdictions of the Länder are affected) bureaucrats are involved in all stages of 
policymaking. Similar to the Bundesrat model, the national governments and their civil servants negotiate rules and orders in numerous supranational and intergovernmental bodies, which are attached to the European Commission, the council of ministers and other EU institutions.

By applying the expertise of sub-federal ministerial bureaucracies in federal legislation during the early stages of policymaking, administrative federalism has actively contributed to professionalising law-making since 1949. Nonetheless, the German model is under pressure for change and has been the subject of critical debate. First, applying the principal-agent theory, it could be argued that German federalism is prone to agency problems. In this regard, ministers as 'principals' are not expected to closely scrutinise their bureaucrats. However, this theory is the subject of controversy; Bogumil et al. suggest that ministers are not always able to enforce their political will, since a growing share of (political) bureaucrats are more inclined to prioritise expertise at the cost of the (politically accountable) minister's political preferences (Bogumil et al. 2012: 166-168). Second, it is beyond question that the administrative (executive) character of cooperative federalism, which also stretches to the EU level, weakens parliaments as the primary principals, mainly at the Länder level (Kropp 2015), because parliaments face difficulties in scrutinising their governments and administrations and untying package deals in the multilevel intergovernmental game. Administrative federalism has undoubtedly secured legal expertise and may improve the quality of legislation, but, as a flipside, it diminishes transparency and complicates accountability. Even though the Bundestag and some resource-strong Länder parliaments participate throughout the executive-driven multilevel processes and have thus managed to enlarge their information and scrutiny rights vis-à-vis their governments in EU affairs (Kropp 2013), this does not counterbalance the deficiencies of input legitimacy.

Third, administrative capacity and financial power are not evenly distributed among the German Länder. Not surprisingly, some of the smaller Länder and city-states face difficulties in drafting their own policy solutions or in implementing laws, even when exclusive jurisdictions, exit options and deviation rights are constitutionally provided. As a result, German federalism is not fully able to exploit its potential to launch competition for best policy solutions and thus fails to serve one of its genuine purposes. Due to weak administrative capacity (which adds to a remarkably unitary federal culture), policymakers do not often tailor regulations and laws to regional needs. Moreover, in intergovernmental bodies, the 
stronger Länder usually dominate the scenery. Overall, the power imbalance among the Länder devitalises federalism, a trend that has been enforced by personnel cutbacks across all levels of public administration.

Finally, federal administrative networks are basically able to generate innovative policy solutions transcending the status quo. Although moderate party politicisation is inherent in intergovernmental bodies, which make decisions with broad majorities or even unanimously, blockades rarely emerge from federal negotiations. In the past, even large-scale reforms were adopted, since party positions converged and moved away from the status quo. The German federal system with its strong institutionalised vetoes, however, will come under pressure if party polarisation further increases. Today, three-party Länder coalitions are often required to achieve a parliamentary majority. As a result, tensions between cabinet members have increased. This may also affect intergovernmental networks because civil servants are obliged to show loyalty to their respective minister, even if, as experts themselves, they have conflicting views. Under these conditions, consensus building and decision-making in the intergovernmental arenas will become increasingly burdensome.

\section{CONCLUSION AND LESSONS LEARNED}

As the above considerations have shown, German federalism cannot properly be understood without appreciating the specific division of functions between the federal and Länder levels, which gives powerful authority to Länder executives and administrations in policymaking (by means of the Bundesrat negotiations) and in implementation (by means of the Länder prerogative). This characteristic and the formation of the Bundesrat as second chamber staffed by members of Länder governments are historic and deeply ingrained in the German federal tradition. The tight institutional entanglement between executives and administrations at both levels of government requires powerful coordination mechanisms. In everyday policymaking, coordination is achieved across multiple arenas, including committees and working groups of intergovernmental coordination and cooperation in which bureaucrats especially play an important role in curtailing conflicts of interest and harmonising policy implementation. The strong administrative influence has proven to be rather efficient. Implementation runs smoothly, and, while regional variation is being accommodated to some degree by the highly decentralised territorial organisation, living conditions are relatively homogenous across the 
German territory (compared to other federal states). However, despite the constitutional requirements to achieve 'equal living conditions' and multiple redistributive programmes, regional disparities have not been eliminated. In an era of policy challenges such as terror prevention, refugee integration, energy transition and digitalisation, the overly complex institutional and procedural architecture of German administrative federalism is constantly being criticised for hindering the development of efficient solutions. According to federal decision-makers, the trend towards even stronger centralisation and unitarisation of policymaking seems to be inherent in new tasks cross-cutting the existing distribution of responsibilities.

In terms of legislation, executive influence on policymaking would, in theory, be prone to causing deadlocks; in practice, however, political conflict is moderated by coordination routines in the intergovernmental arenas. Party affiliation serves to structure coordination procedures, for example, in the A-, B- and G-rounds of pre-plenary coordination in Bundesrat and ministerial conference meetings, but it rarely causes outright blockade. Administrative federalism is criticised for its democratic deficit because parliaments, particularly at the Länder level, are basically disadvantaged in multilevel games. However, to the extent that recent or ongoing trends such as increasing territorial disparities and the fractionalisation of the political landscape undermine efficient policymaking and implementation, it becomes questionable whether the model of administrative federalism will be robust enough to live up to its promise.

\section{REFERENCES}

Behnke, N. (2019). How Bureaucratic Networks Make Intergovernmental Relations Work-A Mechanism Perspective. In N. Behnke, J. Broschek, \& J. Sonnicksen (Eds.), Configurations, Dynamics and Mechanisms of Multilevel Governance (pp. 41-59). Basingstoke: Palgrave Macmillan.

Bogumil, J., Ebinger, F., \& Jochheim, L. (2012). Spitzenbeamte und ihr Verhalten bei politisch relevanten Entscheidungen. In D. Schimanke, S. Veit, \& H. P. Bull (Eds.), Bürokratie im Irrgarten der Politik (pp. 151-156), International Institute of Administrative Sciences /Deutsche Sektion: Schriften der Deutschen Sektion des Internationalen Instituts für Verwaltungswissenschaften, Vol. 36. Baden-Baden: Nomos.

Burkhart, S., \& Manow, P. (2006). Kompromiss und Konflikt im parteipolitisierten Föderalismus der Bundesrepublik Deutschland. Zeitschrift für Politikwissenschaft, 16, 807-824. 
Detterbeck, K. (2012). Multi-level Party Politics in Western Europe (Comparative Territorial Politics Series). Basingstoke, Hampshire: Palgrave.

Frotscher, W., \& Pieroth, B. (2018). Verfassungsgeschichte. München: C.H. Beck. Hegele, Y. (2017). Multidimensional Interests in Horizontal Intergovernmental Coordination: The Case of the German Bundesrat. Publius: The Journal of Federalism, 48(2), 244-268.

Hegele, Y., \& Behnke, N. (2017). Horizontal Coordination in Cooperative Federalism: The Purpose of Ministerial Conferences in Germany. Regional o Federal Studies, 27(5), 529-548. https://doi.org/10.1080/1359756 6.2017.1315716.

Hoffmann, J., \& Wisser, M. (2012). Sachverständige Rechsetzung. Die Ausschüsse des Bundesrates in der Gesetzgebung des Bundes. Zeitschrift für Parlamentsfragen, 43(3), 598-608.

Hueglin, T., \& Fenna, A. (2015). Comparative Federalism (2nd ed.). Toronto: University of Toronto Press.

Hustedt, T., \& Salomonsen, H. H. (2018). From Neutral Competence to Competent Neutrality? Revisiting Neutral Competence as the Core Normative Foundation of Western Bureaucracy. In H. Byrkjeflot, F. Engelstad, \& P. D. Gay (Eds.), Bureaucracy and Society in Transition: Comparative Perspectives (pp. 69-88), Comparative Social Research (Yearbook Series), Vol. 33. Bingley: Emerald Publishing Limited.

Kropp, S. (2013). Information und Kontrolle im Deutschen Bundestag. Exekutive und regierungstragende Fraktionen in europäisierten Fachpolitiken. In B. Eberbach-Born, S. Kropp, A. Stuchlik, \& W. Zeh (Eds.), Parlamentarische Kontrolle und Europäische Union (pp. 179-200). Baden-Baden: Nomos.

Kropp, S. (2015). Federalism and Subnational Parliaments-A Delicate Relationship. In G. Abels \& A. Eppler (Eds.), Subnational Parliaments in an EU Multi-level Parliamentary System: Taking Stock of the Post-Lisbon Era (pp. 91-126). Innsbruck: Studienverlag.

Kuhlmann, S., \& Wollmann, H. (2019). Introduction to Comparative Public Administration: Administrative Systems and Reforms in Europe (2nd ed.). Cheltenham: Elgar.

Mayntz, R., \& Derlien, H.-U. (1989). Party Patronage and Politicization of the West German Administrative Elite 1970-1987-Towards Hybridization? Governance, 2, 384-404.

Mayntz, R., \& Scharpf, F. W. (1975). Policy-Making in the German Federal Bureaucracy. Amsterdam, Oxford, New York, NY: Elsevier.

Mußgnug, R. (1984). Die Ausführung der Reichsgesetze durch die Länder und die Rechstaufsicht. In K. G. A. Jeserich, H. Pohl, \& v. Unruh, G. C. (Eds.), Deutsche Verwaltungsgeschichte Bd. 3: Das Deutsche Reich bis zum Ende der Monarchie (pp. 186-206). Stuttgart: Deutsche Verlags-Anstalt. 
Schwanke, K., \& Ebinger, F. (2006). Politisierung und Rollenverständnis der deutschen administrativen Elite 1970-2005-Wandel trotz Kontinuität. In J. Bogumil, W. Jann, \& F. Nullmeier (Eds.), Politik und Verwaltung. PVSSonderheft 37 (pp. 228-249). Wiesbaden: VS-Verlag.

Souris, A. (2018). Europa im Parteienwettstreit in den Ausschüssen des Bundesrates. Integration, 3, 210-227.

Stecker, C. (2016). The Effects of Federalism Reform on the Legislative Process in Germany. Regional of Federal Studies, 26(5), 603-624. https://doi.org/1 $0.1080 / 13597566.2016 .1236334$.

Sturm, R., \& Müller, M. M. (2013). Blockadepolitik in den Ausschüssen des Bundesrates-Offene Fragen und erste Antworten. In T. Europäisches Zentrum für Föderalismusforschung (EZFF) (Ed.), Jahrbuch des Föderalismus (Vol. 14, pp. 142-154). Baden-Baden: Nomos.

Toubeau, S., \& Massetti, E. (2013). The Party Politics of Territorial Reforms in Europe. West European Politics, 36(2), 297-316.

Weichlein, S. (2012). Föderalismus und Bundesstaat zwischen dem Alten Reich und der Bundesrepublik Deutschland. In I. Härtel (Ed.), Handbuch Föderalismus_Föderalismus als demokratische Rechtsordnung und Rechtskultur in Deutschland, Europa und der Welt. Band I: Grundlagen des Föderalismus und der deutsche Bundesstaat (pp. 101-127). Berlin: Springer.

Open Access This chapter is licensed under the terms of the Creative Commons Attribution 4.0 International License (http://creativecommons.org/licenses/ by $/ 4.0 /$ ), which permits use, sharing, adaptation, distribution and reproduction in any medium or format, as long as you give appropriate credit to the original author(s) and the source, provide a link to the Creative Commons licence and indicate if changes were made.

The images or other third party material in this chapter are included in the chapter's Creative Commons licence, unless indicated otherwise in a credit line to the material. If material is not included in the chapter's Creative Commons licence and your intended use is not permitted by statutory regulation or exceeds the permitted use, you will need to obtain permission directly from the copyright holder.

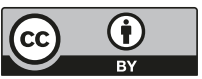

